\title{
LITERASI BACA TULIS DAN KAITANNYA DENGAN PENGEMBANGAN MATERI AJAR BAHASA INDONESIA
}

\author{
Maharani Dwi Putri Asriati \\ Program Magister Fakultas Bahasa dan Seni, Umiversitas Negeri Padang \\ maharanidwipuriasriati@gmail.com
}

\begin{abstract}
Kemampuan literasi pada awalnya diartikan sebagai kemampuan membaca dan menulis, namun pada saat ini pemahaman telah berkembang. Dalam bidang studi, literasi merupakan kemampuan penting yang harus dimiliki setiap siswa untuk menguasai berbagai mata pelajaran. Sesuai dengan penjelasan dalam kurikulum 2013 bahwa bahasa adalah penggerak ilmu pengetahuan, bahasa Indonesia adalah sarana penyampaian ilmu pengetahuan. Literasi adalah dasar dalam pembentukan kepribadian multi-berpendi-dikan. Kurikulum nasional menempatkan penting tugas untuk sekolah dengan meramalkan tujuan pendidikan umum dan persyaratan publik, untuk mengembangkan kompetensi literasi siswa Tavdgiridze (dalam Vivi, et al 2016). Setiap orang yang sudah belajar tentu sering membaca, terutama dalam mengetahui sesuatu dalam bentuk tulisan, kegiatan membaca sangat diperlukan. Membaca melibatkan pikiran untuk memahami dan menginterpretasi lambang bahasa guna memperoleh informasi yang disampaikan penulis dalam tulisannya (dalam Gusnetti, et al 2019).
\end{abstract}

Keterampilan berbahasa anak terutama membaca dan menulis yang diperoleh melalui pelajaran bahasa Indonesia, sangat menentukan keberhasilan mereka dalam menguasai berbagai mata pelajaran lain. Khusus untuk mata pelajaran bahasa Indonesia pengertian literasi lebih dipumpunkan pada keterampilan informasi. Kemampuan informasi mengacu pada beberapa aktivitas, yaitu mengumpulkan informasi, mengolah informasi, dan mengomunikasikan informasi. Ketiga aktivitas tersebut tidak dapat dilepaskan dari keterampilan membaca dan menulis, yang dilaksanakan guru dan siswa dalam proses pembelajaran di kelas. Aktivitas semacam ini sesuai dengan tuntutan proses pembelajaran menurut Kurikulum 2013 yang dikenal dengan istilah pendekatan saintifik. Berkaitan dengan pelaksanaan pembelajaran literasi maka guru harus memperhatikan empat aspek, yaitu sumber belajar, bahan ajar, strategi pembelajaran, dan penilaian. Menurut Agustina (dalam syahrul, et al 2018) pembelajaran bahasa Indonesia di setiap jenjang pendidikan mulai dari sekolah dasar hingga jenjang selanjutnya berorientasi pada peningkatan kemampuan berbahasa Indonesia para siswa. Penguasaan keterampilan berbahasa masih dijadikan sebagai prestasi utama dalam pembelajaran bahasa Indonesia.

Bahasa memiliki peran sentral dalam perkembangan intelektual, sosial, dan emosional peserta didik. Bahasa adalah menunjang keberhasilan dalam belajar. Pembelajaran bahasa diharapkan dapat membantu peserta didik mengenal dirinya sendiri, budayanya, dan orang lain. Di Selain itu, bahasa digunakan untuk mengungkapkan ide dan perasaan, berpartisipasi dalam masyarakat, menemukan dan menggunakan analisis mereka sendiri dan kemampuan imajinatif 
(MoNE, 2007 dalam Novelti, et al). Kemampuan bahasa anak yang diperoleh melalui pembelajaran bahasa Indonesia, khususnya membaca dan menulis, Bahasa memegang peranan penting dalam kehidupan manusia. Bahasa dapat mengembangkan kecerdasan intelektual, emosional, dan kecerdasan spiritual Arief (dalam Ramadhan, et al 2018). Khusus untuk mata pelajaran bahasa Indonesia, konsep literasi berfokus pada keterampilan informasi. Kemampuan informasi mengacu pada berbagai kegiatan, yaitu mengumpulkan informasi, memproses informasi, dan bertukar informasi. Ketiga kegiatan tersebut tidak terlepas dari keterampilan membaca dan menulis yang dilakukan oleh guru dan siswa dalam proses pembelajaran di kelas. Kegiatan semacam ini memenuhi syarat proses pembelajaran mata kuliah 2013 dan disebut metode ilmiah. Dalam pelaksanaan pembelajaran literasi, guru harus memperhatikan empat aspek yaitu, sumber belajar, bahan ajar, strategi pembelajaran dan penilaian.

Literasi sangat berkaitan dalam pengembangan materi ajar. Jika siswa dapat menguasai pelajaran maka pendidikan juga berjalan dengan lancar. Pendidikan sebagai tolak ukur kemajuan bangsa memerlukan perhatian yang komprehensif tentang bagaimana mengembangkan pendidikan berbasis teknologi. Lembaga pendidikan harus menyediakan ruang yang cukup untuk perkembangan teknologi, yang diharapkan dapat membantu proses pembelajaran yang dilakukan di kelas secara efektif (dalam syahrul R, et al 2019). 


\section{DAFTAR PUSTAKA}

Gusnetti, M.Zaim, Syahrul R, dan Agustina. 2019. Pengaruh Teknik Membaca Sq3r Terhadap Membaca Pemahaman Mahasiswa Fkip Universitas Bung Hatta Padang. Jurnal Ta'dib. IAIN Batu Sangkar.

Mulyadi, Syahrul R, dkk. 2019. The Development E-Modules Based on Adobe Flash For Indonesia on Course Indonesian. Atlantis Press.

Novelti, Syahrul, R., Ermanto, Agustina. 2018. Developing an Instructional Model Assisted Audio Visual Media. Atlantis Press.

Sucia, Syahrul R, dkk. 2019. The Development Of Electronic Module Based On Discovery Learning In Writing Explanation Test. Atlantis Press.

Subandiyah, Heny. 2017. Pembelajaran Literasi Dalam Mata Pelajaran Bahasa Indonesia. Paramasastra.

Syahrul Ramadhan, Yasnur Asri, Vivi Indriyani. 2018. Learning Module Design Writing Argumentative Text Based Problem-Based Learning. Atlantis Press.

Vivi Indriyani, M. Zaim, Atmazaki, Syahrul Ramadhan. 2019. Literasi Baca Tulis Dan Inovasi Kurikulum Bahasa. Kembara: Jurnal Keilmuan Bahasa, Sastra, dan Pengajarannya. 